\title{
MAGNETIC ORIENTATION OF THE JATULIAN MAGNETISM IN EASTERN FINLAND. A PRELIMINARY NOTE
}

\author{
K. J. NEUVONEN
}

\begin{abstract}
Neuvonen, K. J. 1975: Magnetic orientation of the Jatulian magmatism in eastern Finland. A preliminary note. Bull. Geol. Soc. Finland 47, 109-112.

The remanent magnetization of subsilicic Jatulian dikes, sills and volcanic beds is described and discussed. The magnetic orientation and pole position are very similar to those measured on Svecokarelian intrusives indicating insignificant plate motion during $2.100-1.900 \mathrm{my}$.

K. J. Neuvonen, Institute of Geology and Mineralogy, University of Turku, SF-20500 Turku 50, Finland.
\end{abstract}

\section{Introduction}

The Jatulian sequence of sedimentary rocks forms the basal cover on the approximately 2700 m.y. old Precambrian gneissous basement complex in eastern Finland and Karelia. The group typically starts with Sariola (Eskola 1925) conglomerate overlain by a thick series of quartzites. These are followed by dolomites and pelitic schists (the so-called Marine Jatuli, Väyrynen 1928).

The Jatulian rocks are frequently accompanied by dikes, sills and effusive beds of subsilicic composition (Väyrynen 1928, Piirainen 1969, Silvennoinen 1972). Some of then are tholeitic but the majority are spilitic. According to Sakko (1971), zircon and sphene yield a radiometric age of $2150 \mathrm{~m} . \mathrm{y}$. for these magmatic rocks.

The Jatulian sequence is well exposed in eastern Finland where a narrow band rich in quartzites starting from north of Lake Ladoga in the south runs to Lapland in the north. The sedimentary rocks of the group are usually devoid of magnetic minerals, and consequently, the magnetic survey of the sequence has to be made on the intrusive dikes and effusive layers. To find out whether these rocks were suitable for this type of work, samples were collected from four different areas in eastern Finland. A total of 32 locations were sampled and tested for magnetic stability.

\section{Stability}

The samples collected were tested for stability using AC demagnetization (Schonstedt GSD-1 demagnetizer) and thermal treatment. They were heated in a one-specimen oven heated by a Bunsen burner so that the temperature as well as 


\section{TABLE 1}

Directions of remanent magnetization of 2150 m.y. old Jatulian dikes and layers in Eastern Finland

Tobmajärvi area, longitude $62.44^{\circ} \mathrm{N}$, latitude $30.32^{\circ} \mathrm{E}$.

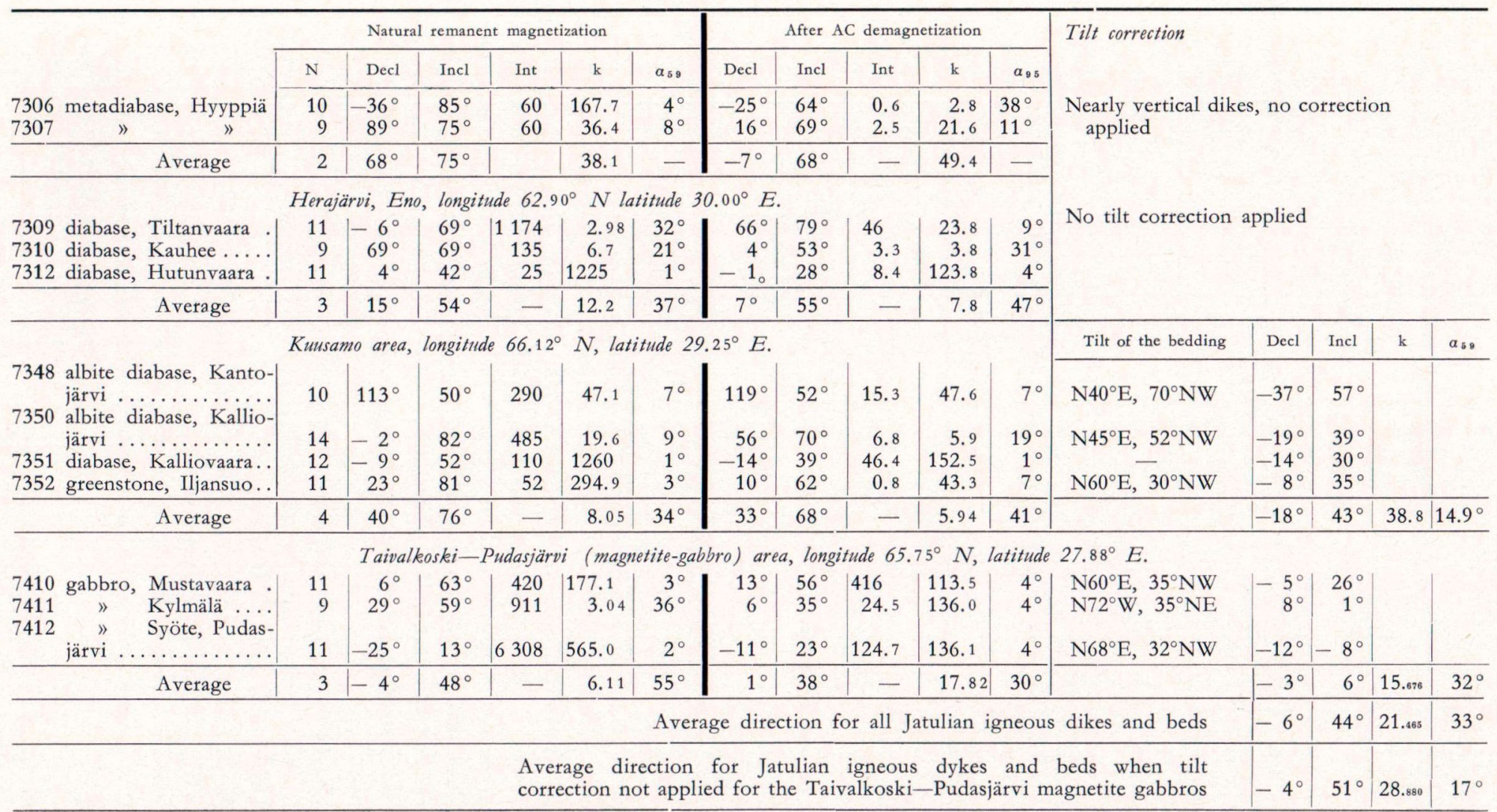

$\mathrm{N}=$ number of specimens or samples included, Int $=$ intensity of the remanent magnetization $\left(10^{-5} \mathrm{emu}\right)$,

$\mathrm{k}=$ precision parameter, $\alpha_{95}=$ circle of confidence with a probability of 95 percent. 
the remanent and induced magnetization were recorded during the heating (and cooling) period. Most of the samples collected turned out to be either too weakly magnetized or unstable and consequently unsuitable for paleomagnetic work. Only twelve of the 32 samples collected contained a stable component permitting the direction of the remanent magnetization to be measured with a Foster type (Foster 1966) spinner magnetometer utilizing a Förster Oersted-meter as a fluxgate.

\section{Magnetic directions}

The magnetic directions obtained are summarized in Table 1.

The directions measured for the Tohmajärvi and Eno area were not corrected for tilt since the dikes are vertical or steeply cutting the sedimentary rocks. No direct indications of tilting of the dikes were observed.

The rocks studied from the Kuusamo area are sills and effusive layers and a tilt correction was essential. The correction applied improved the convergency of the direction so that $\alpha_{95}$ decreased from $41^{\circ}$ to $15^{\circ}$. The magnetite gabbro in the Taivalkoski-Pudasjärvi area has a magmatic layering and it is not quite clear whether a tilt correlation should be made or not. Correction did, in this case, divergent the directions measured and $\alpha_{95}$ increased from $17^{\circ}$ to $33^{\circ}$.

The average paleomagnetic pole position calculated on the basis of the directions given in Table 1 is

\section{Longitude $60^{\circ}$ north and latitude $145^{\circ}$ west with $\alpha_{95}=20^{\circ}$}

if tilt correction is not applied for the Taivalkoski-Pudasjärvi gabbros (if applied, the values would be $58^{\circ} \mathrm{N}$ and $144^{\circ} \mathrm{W}, \alpha_{95}=20^{\circ}$ ). This pole site does not differ greatly from that $\left(45^{\circ} \mathrm{N}, 122^{\circ} \mathrm{W}\right)$ calculated for the $1900 \mathrm{~m} . \mathrm{y}$. old, synorogenic Svecokarelian intrusive rocks (Neuvonen, 1974).

The most reliable part of the present work is that presented by the samples collected from the Kuusamo area. The paleopole based on this area is $47^{\circ} \mathrm{N}$ and $127^{\circ} \mathrm{W}$, which is very close to the $1900 \mathrm{~m} . \mathrm{y}$. pole of the synorogenic intrusive rocks.

Additional samples and more measurements are needed to obtain reliable information concerning the Jatulian paleomagnetic pole position. Even so, the observations made so far indicate that either the plate motion during the time span from $2150 \mathrm{~m} . \mathrm{y}$. to $1900 \mathrm{~m}$.y. was rather limited in the Fennoscandian region or that the magnetization measured on these Precambrian rocks does not originate from the time of the original crystallization of the igneous magma. If the latter is the case, the similarity observed between the magnetic directions in the different and widely separated areas indicates homogenious uplift of the crust in a very large region including at least the eastern and central parts of Finland and northern Sweden.

\footnotetext{
Acknowledgements - Sincere thanks are due to all persons from the Geological Survey of Finland, the Outokumpu and Rautaruukki companies and the University of Oulu who guided and helped me in the collecting of the samples used in this study.
} 


\section{REFERENCES}

Eskola, Pentti (1925) On the petrology of eastern Fennoscandia I. Fennia 45 (19).

Foster, John H. (1966) A paleomagnetic spinner magnetometer using a fluxgate gradiometer. Earth and Planet. Sci. Lett. 1. 463-466.

Neuvonen, K. J. (1974) Paleolatitude and cause of the Svecokarelian orogeny. Bull. Geol. Soc. Finland 46: $75-79$.

Pirrainen, T. (1969) Initialer Magmatismus und seine Einbildung in der Beleuchtung des Koli-KaltimoGebietes. Bull. Geol. Soc. Finland 41: 21-45.
SAKко, Matti (1971) Varhais-karjalaisten metadiabaasien radiometrisiä zirkoni-ikiä. Geologi 23 (9-10): 117-118.

Silvennoinen, Ahti (1972) On the stratigraphic and structural geology of the Rukatunturi area, northeastern Finland. Bull. Geol. Surv. Finland 257: $1-48$.

Väyrynen, Неiккi. (1928) Geologische und petrographische Untersuchungen in Kainuugebiet. Bull. Comm. Géol. Finlande 78.

Manuscript received, February 7, 1975. 